\title{
Citizens Satisfaction with Local Governments in Argentine: Key Predictors
}

\author{
Héctor Oscar Nigro (Corresponding Author) \\ Instituto de Investigación en Tecnología Informática Avanzada, Universidad Nacional del \\ Centro de la Provincia de Buenos Aires \\ Campus Universitario Paraje Arroyo Seco s/n, Tandil, Argentina \\ Tel: 02293-15619502Ｅ-mail: oscarnigro@speedy.com.ar
}

Received: September 18, 2011 Accepted: December 17, 2011 DOI: 10.5296/jpag.v2i1.1086

\begin{abstract}
The causes which influence the Citizens Satisfaction with Local Governments may be direct or indirect, and for this reason much research has been developed with the objective to discover a model or methodology. For this work was taken as a measurement instrument to collect data a questionnaire based on a model that adapts to the data from an integrated between the European Consumer Satisfaction Index (ECSI) (Eklöf, 2000) and the ECSI revised Chenn (Chenn, 2009) as a representation of domain knowledge. With a structured interview card and pre-coded, the sample design adopted was probabilistic multistage cluster with selectable final drive to set quotas for sex, age and area. We selected surveyed between over 18 years citizens of Tandil (Argentine) of 123,000 inhabitants. This city divided into zones based on socioeconomic characteristics and obtained 401 valid questionnaires. We found that the model explained $65 \%$ of citizen satisfaction and $55 \%$ of the loyalty of the same with the local leadership.
\end{abstract}

Keywords: Citizen Satisfaction with Local Governments. Structural Equation Model. Partial Least Square. European Consumer Satisfaction Index. 


\section{Macrothink}

Journal of Public Administration and Governance

ISSN 2161-7104

2012, Vol. 2, No. 1

\section{Introduction}

The primary study endpoint is the measurement of service quality discovering the variables or intangible factors more influential in citizen satisfaction of local government. The original ECSI model is a variation of the ACSI model (Eklöf, 2000). These rates of citizen satisfaction as statistical indicators have to know most effectively the manner in which different variables influence on customer satisfaction and how the latter affects others. Relevant intangibles are defined to measure citizen satisfaction for each of these concepts, defines indicators that measure.

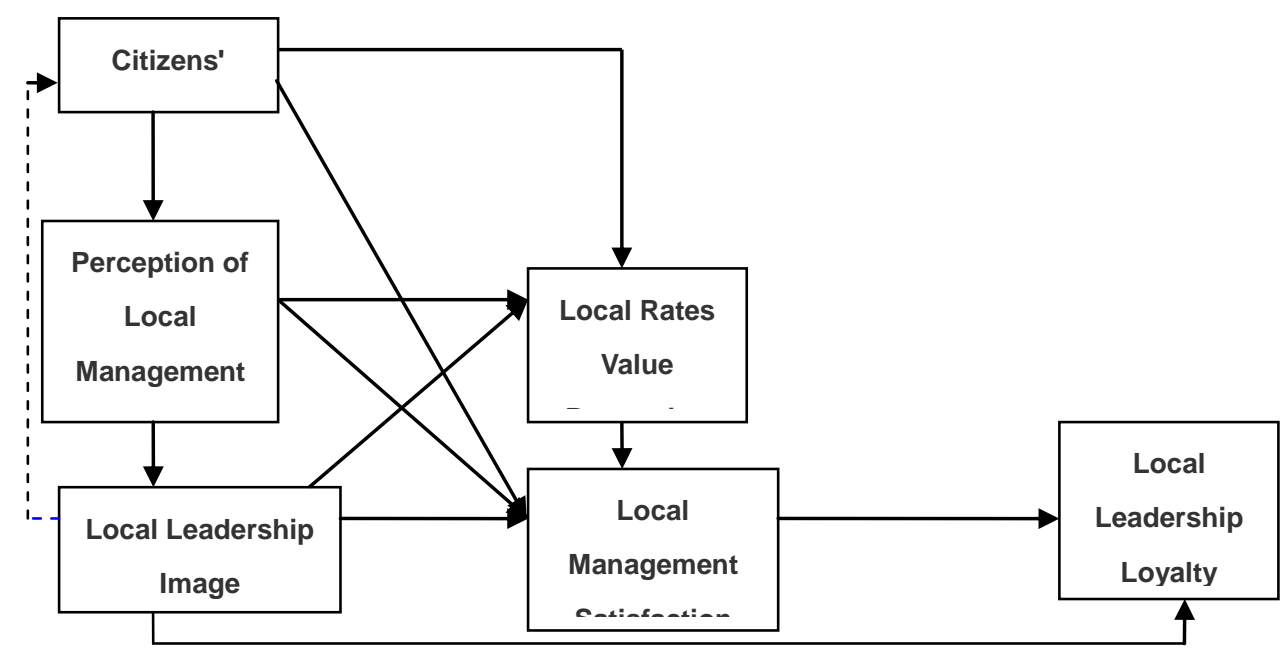

Figure 1: Proposed model developed based on the original ECSI and ECSI revised for Chenn.

The shaded arrow image with expectations linking corresponds to original ECSI model, but the link with the ECSI revised model Chenn (Chenn, 2009), we note a contradiction or cycle is not accepted by some software models. Is maintained link between perceptions of quality of service and image and consider the Expectation as an exogenous variable therefore not be taken into consideration the relationship Image and Expectations. 


\section{Instrument of Measuring, Questionnaire Design and Sample Preparation.}

The design of the questionnaire is to identify the indicators and dimensions of each of the concepts or constructs that directly or indirect affect citizen satisfaction as a user of public administration services. It analyzes the development of different constructs, consisting of four stages (Lazarsfeld, 1985): Literary representation of the concept, Concept Specification, The election of the observable indicators and Prepare indices or measures.

It defines the concepts relevant intangibles that measure citizen satisfaction. Of each concept identifies the indicators that measure and make the association between each indicator and the question referred to in the questionnaire.

The concepts and indicators or indices made with their definitions are:

Tabla 1: Literary Representation and Specification of the Concept

\begin{tabular}{|c|c|}
\hline $\begin{array}{l}\text { Literary representation of } \\
\text { the concept }\end{array}$ & Concept Specification \\
\hline Citizens' expectations & $\begin{array}{l}\text { Represents the reference level expected by the } \\
\text { citizens on three aspects: personal expectation, } \\
\text { expectations about the growth of the city and country }\end{array}$ \\
\hline $\begin{array}{l}\text { Perception of Value of the } \\
\text { Municipal Rates }\end{array}$ & $\begin{array}{l}\text { Represents the relation between the quality of public } \\
\text { services provided by government and municipal taxes } \\
\text { received by the citizens on the service received. }\end{array}$ \\
\hline Local Leadership Image & $\begin{array}{l}\text { This factor evaluates the brand image of the } \\
\text { citizen-consumer of the local government executive } \\
\text { leadership as a whole and the services it offers. } \\
\text { Represents the set of beliefs and associations that are } \\
\text { levied on the characteristics and charisma of local } \\
\text { leadership and action. }\end{array}$ \\
\hline Satisfaction Citizen & $\begin{array}{l}\text { Represents the attitude or psychological state to the } \\
\text { citizen who receives services provided by } \\
\text { government, and your experience with the service }\end{array}$ \\
\hline
\end{tabular}




\begin{tabular}{|c|c|}
\hline & product \\
\hline eadership Loyalty & $\begin{array}{l}\text { Represents the ability of local leadership and public } \\
\text { management team has to keep loyal to the citizens } \\
\text { about their goals and initiatives. }\end{array}$ \\
\hline $\begin{array}{lr}\text { Perception of } & \text { Local } \\
\text { Management } & \text { Service } \\
\text { Quality } & \end{array}$ & $\begin{array}{l}\text { Key component that determines customer satisfaction } \\
\text { according to the way it has experienced the service. } \\
\text { This factor has a very strong relationship with } \\
\text { satisfaction of the citizen. Quality of Public Services } \\
\text { requires research and knowledge of other } \\
\text { relationships (Zeithaml et al, 1996), the performance } \\
\text { of operations carried implemented by the public } \\
\text { organization and technical aspects related products / } \\
\text { services offered, the performance of linked } \\
\text { relationships to the functional aspects of products / } \\
\text { services offered by the public organization, and } \\
\text { organizational performance related to the generic } \\
\text { aspects of the organization (responsiveness and } \\
\text { image, along with reliability and responsibility). } \\
\text { In our case, approval is sought from different areas } \\
\text { and then group them into general concepts relate to } \\
\text { each other and with other latent variables }\end{array}$ \\
\hline
\end{tabular}

In the questionnaire measures each variable manifest on a scale based on 1 to 10 , with 1 very negative and 10 very positive.

\section{Reduction of space dimensions, Perceived quality of services.}

With the objective to reduce the space dimensions in the manifest variables for Perceived Quality of Services, applies the exploratory factor analysis. We must find the least number of common factors to take into account correlations between variables or variances. Method is applied Varimax orthogonal rotation method that minimizes the number of variables that have 
high loadings on each factor. It simplifies the interpretation of the factors, and excluding all cases with missing values in any of the different variables used in the analysis (listwise Exclude).

First analyze the factors whose eigenvalue is greater than 1 . The rotation phase of factor analysis is to transform the initial matrix into one that is easier to interpret. The purpose of rotation is achieved a simple structure. This means that we want every factor weights or loadings have non-zero only for some of the variables. This will help us interpret the meaning of the factors. There are seven factors that collected $65.2 \%$ of the variance.

Table 2: Eigenvalues and variance percentages projected rotated factors

\begin{tabular}{|l|l|l|l|}
\hline Factor & Total & \% Of Variance & \% Accumulated \\
\hline 1 & 4,659 & 16,066 & 16,066 \\
\hline 2 & 3,314 & 11,426 & 27,492 \\
\hline 3 & 3,202 & 11,040 & 38,533 \\
\hline 4 & 2,901 & 10,004 & 48,537 \\
\hline 5 & 2,638 & 9,096 & 57,633 \\
\hline 6 & 2,208 & 7,614 & 65,247 \\
\hline 7 & 1,664 & 5,738 & 70,986 \\
\hline
\end{tabular}

After Varimax orthogonal rotation extracted seven factors we observed that the variance explained, the first factor contains $16.1 \%$ of the total variance.

Table 3 shows the loadings of the seven factors that we have retained. Weights considered significant those whose value is greater than 0.40 (Aznar, 1974), Table 3 not only be interpreted as the weights of each variable in each of the seven factors, but as the representativeness of each of the variables in each factor.

In some representativeness or significance variables is exclusive to a single factor such as Children \& Adolescents Development, Social Care Services for Disabled People and Office of Senior Citizen Affairs in Factor 1, or to support micro entrepreneurs in the Factor 4. Other variables are significant simultaneously on several factors such as variable Noise Control, which is significant in factor 1 and 4 . 
Table 3 Rotated Component Matrix

\begin{tabular}{|c|c|c|c|c|c|c|c|}
\hline & \multicolumn{7}{|c|}{ Component } \\
\hline & 1 & 2 & 3 & 4 & 5 & 6 & 7 \\
\hline Children \& Adolescents Development & 0,85 & & & & & & \\
\hline Social Care Services for Disabled People & 0,84 & & & & & & \\
\hline Office of Senior Citizen Affairs & 0,83 & & & & & & \\
\hline Local Youth Support & 0,78 & & & & & & \\
\hline Local Economic Development for Employment & 0,52 & & & & & & \\
\hline Generation & & & & & & & \\
\hline Environmental Care \& Conservation & 0,50 & & & & & & \\
\hline Land clearing & & 0,78 & & & & & \\
\hline Street sweeping and cleaning & & 0,77 & & & & & \\
\hline Maintains and repairs all paved roads and streets. & & 0,74 & & & & & \\
\hline Maintains and repairs all unpaved roads and streets. & & 0,70 & & & & & \\
\hline Asphalt Streets, New Pavement & & 0,63 & & & & & \\
\hline Management of Children's Hospital & & & 0,79 & & & & \\
\hline Health Centers in the neighborhoods & & & 0,77 & & & & \\
\hline Management of the Hospital & & & 0,73 & & & & \\
\hline Performance of community centers & & & 0,54 & & & & \\
\hline Support for micro-entrepreneurs & & & & 0,81 & & & \\
\hline Labor training and entrepreneurial & & & & 0,80 & & & \\
\hline Industrial Promotion & & & & 0,75 & & & \\
\hline Maintaining the industrial park & & & & 0,50 & & & \\
\hline Security Policy & & & & & 0,83 & & \\
\hline Control of night. & & & & & 0,82 & & \\
\hline Noise Control & 0,42 & & & & 0,59 & & \\
\hline Traffic Control & & & & & 0,55 & & \\
\hline Street Lighting Policy & & & & & & 0,80 & \\
\hline Parks, Promenades \& Planning & & & & & & 0,69 & \\
\hline Sidewalk Construction, Maintenance and Repair & & & & & & 0,62 & \\
\hline Local Authority Waste \& Recycling & & & & & & 0,47 & \\
\hline Promotion of sporting activities. & & & & & & & 0,69 \\
\hline Promotion of cultural activities. & & & & & & & 0,59 \\
\hline
\end{tabular}

Extraction Method: Principal Component Analysis.

Rotation Method: Varimax with Kaiser Normalization.

Rotation converged in 7 iterations.

The first element that is observed in the output of the procedure is the correlation matrix whose determinant is $1.51 \mathrm{E}-009$ at very small indicates that the degree intercorrelation between the variables is very high, initial condition to be met by the component analysis main. 


\section{Macrothink \\ Journal of Public Administration and Governance \\ ISSN 2161-7104 \\ 2012, Vol. 2, No. 1}

The Bartlett sphericity test permits formally compare the existence of correlation between variables. As the p-value is 0.000 , we can conclude that there is significant correlation between variables. The KMO statistic is close to unity, 0.852 indicating a good fit of the sample.

Table 4 KMO and Bartlett's test

\begin{tabular}{|cc|c|}
\hline \multicolumn{2}{|c|}{$\begin{array}{c}\text { Measure of sampling adequacy } \\
\text { Kaiser-Meyer-Olkin. }\end{array}$} &, 852 \\
Bartlett test of & Approximate & \\
sphericity & Chi-square & 2223,881 \\
& & \\
& gl & 406 \\
& Sig. &, 000 \\
\hline
\end{tabular}

The reproduced correlation matrix residuals are calculated between the observed and reproduced correlations, $114(28.0 \%)$ nonredundant residuals with absolute values greater than 0.05 , indicating that the goodness of the model is acceptable.

In the first factor there are a total of six significant variables (with weights greater than 0.4). Based on the theoretical factors underlying "Social Services Quality Perception" chose the six variables in question: Children \& Adolescents Development, Social Care Services for Disabled People, Office of Senior Citizen Affairs, Local Youth Support, Local Economic Development for Employment Generation, Environmental Care \& Conservation.

The second factor has five variables: Street sweeping and cleaning, Street sweeping and cleaning, Maintains and repairs all paved roads and streets, Maintains and repairs all unpaved roads and streets, Asphalt Streets and New Pavement. This factor will call Urban Development Process Perception.

The third factor we will call the Quality Perception Process Industry and Enterprise Development, formed by the variables: Labor training and entrepreneurial, Industrial Promotion, Maintaining the industrial park.

Other factors are: 4) Quality Perception of Municipal Health Services Provision (Management of Children's Hospital, Health Centers in the neighborhoods, Management 
of the Hospital, Performance of community centers), 5) Perception of control and compliance of norms (Security Policy, Control of night, Noise Control, Traffic Control), 6) Public Space Maintenance (Street Lighting Policy, “Parks, Promenades \& Planning”, “Sidewalk Construction, Maintenance and Repair”, Local Authority Waste \& Recycling), and 7) Cultural and Sports Events Organization (Promotion of sporting activities and Promotion of cultural activities)

In a second instance theoretical constructs are made two second order:

a) Perception of Urban Development and Maintenance of Public Space, which includes the first-order latent variables: Urban Development Process and Public Space Maintenance and

b) Perceived Quality of Social Services, Employment and Health, formed by the first-order latent variables, Cultural and Sports Events Organization and Quality Perception of Municipal Health Services Provision and Social Services Quality Perception.

\section{Results.}

\subsection{The Measurement Model}

We have used the software package Warp Pls, selecting as the bootstrapping method of sampling, using a method known as "re sampling with replacement" and the number of re sampling used was 100 (Efron et al ,2004). The algorithm for SEM analysis was Warp3 PLS regression.

Table 5: Latent Variables and references

\begin{tabular}{|l|l|}
\hline$(1)$ & Perception of Urban Development and Maintenance of Public Space \\
\hline$(2)$ & Perceived Quality of Social Services, Employment and Health \\
\hline$(3)$ & Local Leadership Loyalty \\
\hline$(4)$ & Local Leadership Image \\
\hline$(5)$ & Satisfaction Citizen \\
\hline$(6)$ & Perception of control and compliance of norms \\
\hline$(7)$ & Citizens' expectation \\
\hline
\end{tabular}


The Table 6 describes the convergent validity of the measuring instrument. A measuring instrument has good convergent validity if the manifest variables (or other measures) associated with each latent variable are understood by respondents in the same manner they were meant by the designers of the manifest variables. Two criteria are recommended as a basis for concluding that a measurement model is acceptable in relation to convergent validity when the value has a charge associated $\mathrm{p}$ less than .05 , and the charges are equal to or greater than 0.5 (Hair et al, 1987). The convergent validity of each factor was tested by examining the standardized factor loadings. Hair et al (Hair et al, 2006), suggest that load factors should be 0.50 or higher, and ideally 0.70 or higher. 
Table 6: Indicator loadings and cross-loadings

\begin{tabular}{|c|c|c|c|c|c|c|c|}
\hline & $\begin{array}{l}(1) \\
(* *)\end{array}$ & $\begin{array}{l}(2) \\
(* *)\end{array}$ & (3) & (4) & (5) & (6) & (7) \\
\hline $\begin{array}{l}\text { Urban Development Process Perception } \\
\qquad(*)\end{array}$ & 0.85 & 0.01 & 0.01 & 0.02 & -0.14 & 0.08 & 0.08 \\
\hline Public Space Maintenance $(*)$ & 0.90 & -0.01 & -0.01 & -0.02 & 0.14 & -0.08 & -0.08 \\
\hline $\begin{array}{l}\text { Cultural and Sports Events } \\
\text { Organization }(*)\end{array}$ & 0.04 & 0.76 & -0.08 & -0.01 & 0.03 & -0.10 & 0.09 \\
\hline $\begin{array}{l}\text { Quality Perception of Municipal Health } \\
\text { Services Provision }(*)\end{array}$ & -0.01 & 0.67 & 0.26 & -0.03 & -0.16 & -0.07 & 0.11 \\
\hline Social Services Quality Perception (*) & 0.21 & 0.90 & -0.08 & -0.00 & -0.10 & -0.09 & -0.16 \\
\hline $\begin{array}{l}\text { Quality Perception Process Industry } \\
\text { and Enterprise Development }(*)\end{array}$ & -0.12 & 0.75 & -0.04 & -0.02 & 0.05 & 0.09 & 0.03 \\
\hline $\begin{array}{l}\text { If the election were held today intention } \\
\text { to vote the current administration. }\end{array}$ & 0.00 & 0.00 & 1.00 & 0.00 & -0.00 & -0.00 & 0.00 \\
\hline Determined to solve people's problems. & -0.03 & -0.01 & 0.17 & 0.57 & 0.22 & 0.08 & -0.14 \\
\hline It is up to future challenges. & 0.02 & -0.02 & 0.20 & 0.56 & 0.06 & 0.06 & 0.01 \\
\hline It has the authority to govern. & 0.01 & -0.02 & -0.25 & 0.70 & 0.30 & 0.02 & -0.15 \\
\hline Good projects. & -0.00 & -0.06 & 0.23 & 0.70 & -0.04 & 0.03 & 0.06 \\
\hline Trustworthy & -0.11 & 0.04 & -0.11 & 0.98 & -0.00 & 0.02 & -0.04 \\
\hline Ability to do things. & 0.06 & -0.01 & -0.29 & 0.99 & -0.03 & -0.07 & 0.09 \\
\hline Honest. & -0.05 & 0.09 & -0.24 & 1.02 & -0.15 & -0.07 & 0.06 \\
\hline
\end{tabular}




\begin{tabular}{|c|c|c|c|c|c|c|c|}
\hline Executive decided. & -0.02 & 0.02 & -0.36 & 1.08 & -0.05 & -0.06 & 0.03 \\
\hline Social awareness & 0.04 & 0.07 & 0.27 & 0.62 & -0.12 & -0.03 & -0.01 \\
\hline Management of the mayor. & -0.04 & -0.13 & 0.13 & -0.05 & 0.82 & 0.04 & 0.17 \\
\hline $\begin{array}{l}\text { Management of the government team } \\
\qquad \text { as a whole }\end{array}$ & -0.06 & 0.02 & 0.05 & -0.09 & 0.94 & 0.01 & 0.04 \\
\hline $\begin{array}{l}\text { Qualification for the overall } \\
\text { management of services and attributes } \\
\text { of the municipal management }\end{array}$ & 0.12 & 0.14 & -0.28 & 0.17 & 0.84 & -0.07 & -0.25 \\
\hline Noise Control & 0.08 & 0.16 & -0.10 & 0.02 & -0.01 & 0.63 & -0.06 \\
\hline Control of night. & 0.02 & -0.07 & 0.02 & 0.01 & -0.08 & 0.88 & 0.08 \\
\hline Traffic Control & -0.12 & 0.09 & -0.01 & 0.04 & 0.00 & 0.68 & -0.02 \\
\hline Security Policy & 0.01 & -0.14 & 0.08 & -0.05 & 0.08 & 0.90 & -0.02 \\
\hline $\begin{array}{l}\text { Assessing the status of Municipal } \\
\text { Government in respect of a year ago. }\end{array}$ & 0.02 & -0.08 & 0.25 & -0.08 & 0.11 & 0.07 & 0.69 \\
\hline $\begin{array}{l}\text { Estimated municipal government in the } \\
\text { coming years. }\end{array}$ & -0.16 & 0.01 & -0.01 & 0.05 & 0.24 & 0.02 & 0.67 \\
\hline $\begin{array}{c}\text { Assessing the situation of the city about } \\
\text { a year ago. }\end{array}$ & 0.13 & -0.01 & -0.06 & 0.01 & -0.27 & -0.03 & 1.00 \\
\hline $\begin{array}{l}\text { Estimation of the evolution of the city } \\
\text { in the coming years }\end{array}$ & 0.01 & 0.01 & -0.20 & 0.02 & -0.09 & -0.07 & 0.96 \\
\hline
\end{tabular}

All $\mathrm{p}$ values are $<0.001$, only for reflective and moderating indicators. $\left.{ }^{*}\right)$ Latent variables. (**) Second-order constructs.

To test the reliability of the measuring instrument and discriminant validity of using R-square coefficients are provided only for endogenous latent variables, and reflect the percentage of 
variance explained by each of the latent variables. Composite reliability and Cronbach alpha coefficients are provided for all latent variables, and are measures of reliability. Average Variance Extracted (AVE) is also available for all latent variables and are used in the assessment of discriminant validity.

A measuring instrument has good reliability if the manifest variables (or other measures) associated with each latent variable are understood in the same way by different respondents. Composite Reliability and Cronbach's alpha coefficients must be equal to or greater than 0.7 (Fornell \& Larcker, 1981), (Nunnally \& Bernstein, 1994), (Nunnaly, 1978). The relaxed version of this criterion, which is widely used, is that one of the two coefficients must be equal to or greater than 0.7 . This usually applies to the composite reliability coefficients, which is usually the greater of the two (Fornell \& Larcker, 1981). A more relaxed version even puts this threshold at 0.6 (Nunnaly, 1978). If a latent variable does not meet any of these criteria, the reason is usually that one or a few indicators have a low load on the latent variable. These indicators should be removed from the model.

AVE is normally used in combination with the correlations of latent variables in the evaluation of the discriminant validity of a measuring instrument.

Table 7: R-squared coefficients, Composite realibility coefficents, Cronbach alpha coefficients and Average Variances Extracted

\begin{tabular}{|c|c|c|c|c|}
\hline $\begin{array}{l}\text { Latent variable } \\
\text { coefficients }\end{array}$ & $\begin{array}{l}\text { R-squared } \\
\text { coefficients }\end{array}$ & $\begin{array}{l}\text { Composite } \\
\text { reliability } \\
\text { coefficients }\end{array}$ & $\begin{array}{l}\text { Cronbach alpha } \\
\text { coefficients }\end{array}$ & $\begin{array}{l}\text { Average } \\
\text { Variances } \\
\text { Extracted }\end{array}$ \\
\hline (1) & & 0,870 & 0,700 & 0,769 \\
\hline (2) & 0,385 & 0,870 & 0,813 & 0,573 \\
\hline (3) & 0,545 & 1,000 & 1,000 & 1,000 \\
\hline (4) & 0,318 & 0,943 & 0,933 & 0,626 \\
\hline (5) & 0,650 & 0,896 & 0,824 & 0,744 \\
\hline (6) & 0,284 & 0,860 & 0,781 & 0,609 \\
\hline (7) & & 0,896 & 0,845 & 0,683 \\
\hline
\end{tabular}


The results generated are tables containing the correlations of latent variables, and $\mathrm{p}$ values associated with these correlations. On the diagonal of the table of correlations between latent variables are the square roots of average variance extracted for each latent variable. These results are used to evaluate the discriminant validity of the measuring instrument.

Table shows the correlations between latent variables, with the square roots of average variance extracted in the diagonal, the measuring instrument is widely accepted by the evaluation criteria of discriminant validity. A measuring instrument has good discriminant validity if the manifest variables (or other measures) associated with each latent variable are not confused by the participants in the survey with the manifest variables related to other latent variables, particularly in terms of their meaning.

The square root of the average variance extracted should be greater than any of the correlations that include the latent variable (Fornell \& Larcker, 1981). The values of the diagonal should be greater than any value above or below them in the same column. $\mathrm{O}$, the values of the diagonal should be higher than any of the values to the left or right, in the same row, which means the same as the above statement, taking into account the repeated values of the latent variable of the table of correlations.

Table 8: Correlations among latent variables

\begin{tabular}{|c|c|c|c|c|c|c|c|}
\hline & (1) & (2) & (3) & (4) & (5) & (6) & (7) \\
\hline \multicolumn{8}{|l|}{ (1) } \\
\hline & 0.877 & 0.565 & 0.364 & 0.395 & 0.479 & 0.532 & 0.338 \\
\hline (2) & 0.565 & 0.757 & 0.466 & 0.550 & 0.550 & 0.521 & 0.459 \\
\hline (3) & 0.364 & 0.466 & 1.000 & 0.693 & 0.649 & 0.270 & 0.512 \\
\hline (4) & 0.395 & 0.550 & 0.693 & 0.791 & 0.686 & 0.326 & 0.554 \\
\hline \multicolumn{8}{|l|}{ (5) } \\
\hline & 0.479 & 0.550 & 0.649 & 0.686 & 0.863 & 0.352 & 0.701 \\
\hline (6) & 0.532 & 0.521 & 0.270 & 0.326 & 0.352 & 0.780 & 0.271 \\
\hline (7) & 0.338 & 0.459 & 0.512 & 0.554 & 0.701 & 0.271 & 0.826 \\
\hline
\end{tabular}

Square roots of average variances extracted (AVE's) shown on diagonal. All $\mathrm{p}$ values for correlations are $<.001$ 


\section{Macrothink}

\subsection{The structural model}

Although latent variables that point to the value of the rates, we refer to perceptions of public space maintenance and development, expectations and images, are significant value as a variable rate that influences citizen satisfaction has a path coefficient low (0.015) and $\mathrm{p}$ high (0.324), so do not take into account this relation and the above. The value of fees is a latent variable that influences a model of citizen satisfaction in local government, at least in this context.

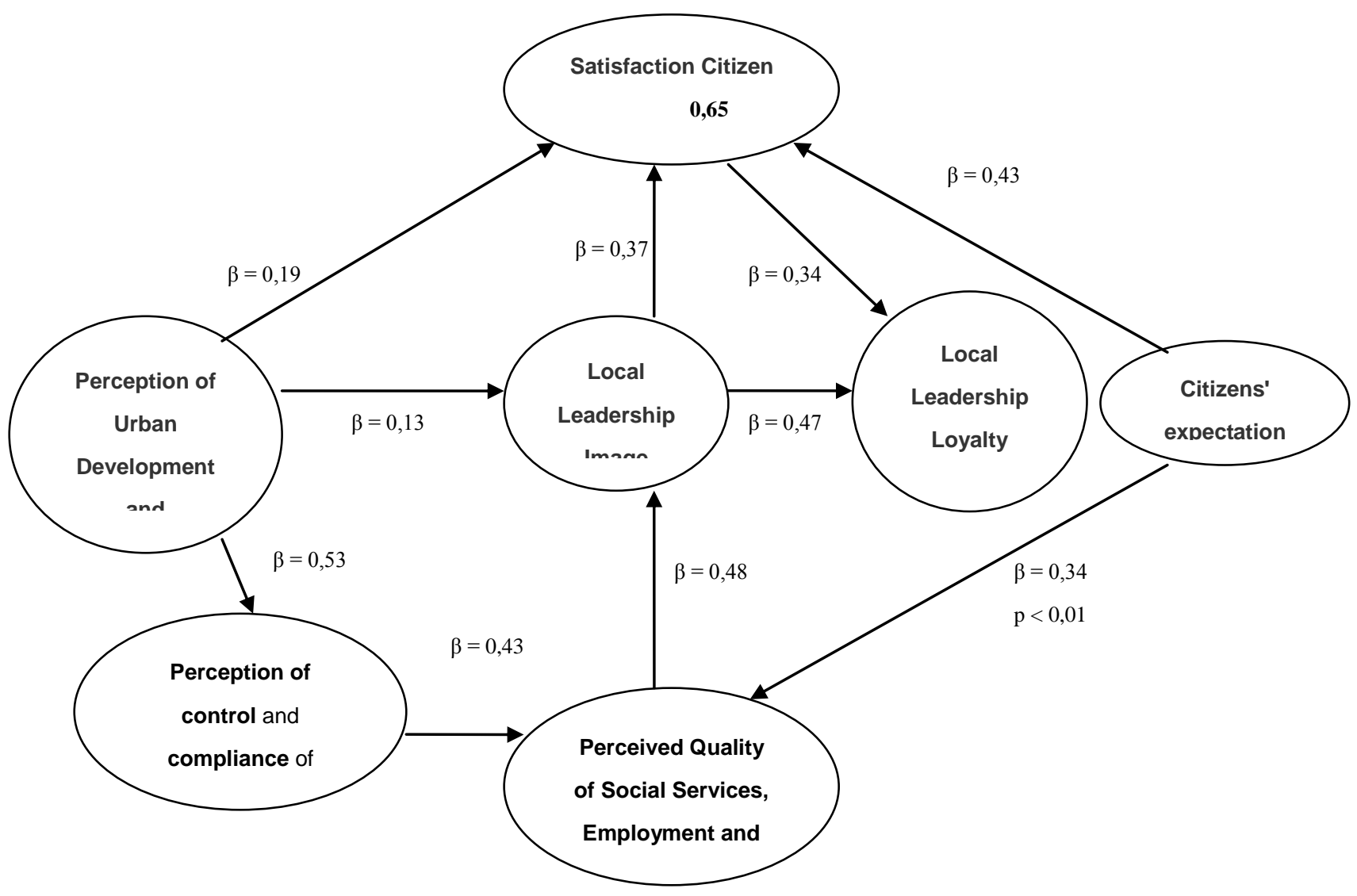

Figure 2 Structural Model of Citizen Satisfaction with Local Governments

The model fit indices that are provided:

a) Average coefficients of the paths (APC),

b) Average R-squared ( ARS), and

c) the average inflation factor of variance (AVIF ). 
For APC and ARS, $\mathrm{p}$ values are provided. These $\mathrm{p}$-values are calculated through a complex process involving re estimates of sampling, estimates are made with Bonferroni corrections. Our goal is to determine if a model has a better fit with the original data than another, then the model fit indices are a useful set of measures related to the quality model. It is recommended that $\mathrm{P}$ values for APC and ARS is both less than 0.05 , ie, that are significant at the 0.05 level, and secondly that AVIF less than 5.

Model fit indices and $\mathrm{P}$ values

$$
\begin{aligned}
& \mathrm{APC}=0.371, \mathrm{P}=<0.001 \\
& \mathrm{ARS}=0.436, \mathrm{P}=<0.001 \\
& \mathrm{AVIF}=1.444, \text { Good if }<5
\end{aligned}
$$

General model elements

Algorithm used in the analysis: Warp3 PLS regression

Resampling method used in the analysis: Bootstrapping

Number of data resamples used: 100

Number of cases (rows) in model data: 401

Number of latent variables in model: 7

Number of indicators used in model:29

Number of iterations to obtain estimates: 10 
Table 9: Path coefficients and P values

\begin{tabular}{|c|c|c|c|c|c|c|c|}
\hline & (1) & (2) & (3) & (4) & (5) & (6) & (7) \\
\hline (1) & & & & & & & \\
\hline (2) & & & & & & $\begin{array}{l}0.429 \\
(<0,001)\end{array}$ & $\begin{array}{l}0.340 \\
(<0,001)\end{array}$ \\
\hline (3) & & & & $\begin{array}{l}0.467 \\
(<0,001)\end{array}$ & $\begin{array}{l}0.337 \\
(<0,001)\end{array}$ & & \\
\hline (4) & $\begin{array}{l}0.131 \\
(0,011)\end{array}$ & $\begin{array}{l}0.481 \\
(<0,001)\end{array}$ & & & & & \\
\hline (5) & $\begin{array}{l}0.191 \\
(<0,001)\end{array}$ & & & $\begin{array}{l}0.370 \\
(<0,001)\end{array}$ & & & $\begin{array}{l}0.433 \\
(<0,001)\end{array}$ \\
\hline (6) & $\begin{array}{l}0.533 \\
(<0,001)\end{array}$ & & & & & & \\
\hline (7) & & & & & & & \\
\hline
\end{tabular}

In Table 9 each path coefficient is shown in a cell, the column represents the latent predictor variable and the row represents the criterion. For example, consider the case where the sample cell 0.131, and the column refers to the latent variable "Perception of Urban Development and Maintenance of Public Space" and the row to the latent variable "Local Leadership Image ". This means that the path coefficient associated with the arrow pointing to "Local Leadership Image" for "Perception of Urban Development and Maintenance of Public Space" is 0.131. Since the results refer to standardized variables, this means that a variation of one standard deviation in the "Perception of Urban Development and Maintenance of Public Space" leads to a variation of the standard deviation of 0.131 "Local Leadership Image".

The variance inflation factors are presented in table format for each latent variable has two or more predictors. Each variance inflation factor associated with a prediction, and is related to the link between this prediction and its latent variable approach. 
Table 10:Variance inflation factors

\begin{tabular}{|c|c|c|c|c|c|c|c|}
\hline & (1) & (2) & (3) & (4) & (5) & (6) & (7) \\
\hline (1) & & & & & & & \\
\hline (2) & & & & & & 1.093 & 1.093 \\
\hline (3) & & & & 1.832 & 1.832 & & \\
\hline (4) & 1.440 & 1.440 & & & & & \\
\hline (5) & 1.210 & & & 1.566 & & & 1.486 \\
\hline (6) & & & & & & & \\
\hline (7) & & & & & & & \\
\hline
\end{tabular}

The VIFs are for the latent variables on each column (predictors), with reference to the latent variables on each row (criteria). - VIFs only exist for rows referring to latent variables with more than one predictor.

The inflation factor for the variance is the measure of the degree of multicollinearity between the latent variables that affect in one hypothesis to another latent variable. For example, let us assume that there is a block of latent variables in a model with three latent variables A, B and C (predictors) that points to the latent variable D. In this case, the factors of variation of inflation are calculated for A, B, and C, and are estimates of multicollinearity between these latent predictors.

Two criteria, a more conservative and a more relaxed, recommended in relation to the factors of inflation in the variance. More conservative inflation factor of variance is less than 5, a more relaxed is to be less than 10 (Hair et al 1987); (Kline, 1998). High variance inflation factors usually occur in pairs of latent variables predictor, suggesting that the latent variables measure the same thing, which calls for the removal of one of the latent variables in the block, or model. 


\section{Conclusions and future work}

The relationship between variable "Perception of Urban Development and Maintenance of Public Space" and the variable "Perception of control and compliance of norms" (Figure 3), we can interpret from the work of James Q Wilson and George L. Kelling (Wilson \& Kelling, 1982). According to these authors, the anxiety in many districts about to security resides in the fear of crime "real", and the sensation that the streets when they are disordered, is a meeting place disagreeable and alarming. People give a high value on order, and are comforted and secure when the local government helps them maintain that order, these citizens recognize a connection between disorder and fear. Following these authors for "regular" residents of community, disorder and crime are inextricably linked in a developmental sequence. Rupture of windows occurs because one unrepaired window is a sign that nobody cares, so breaking more windows costs nothing. Even the proliferation of graffiti, even if not obscene, confronts the citizen with the inescapable knowledge that the environment that supports day is out of control, and that anyone can invade and cause damage that the mind can imagine, and this process the authors characterize as "urban decay".

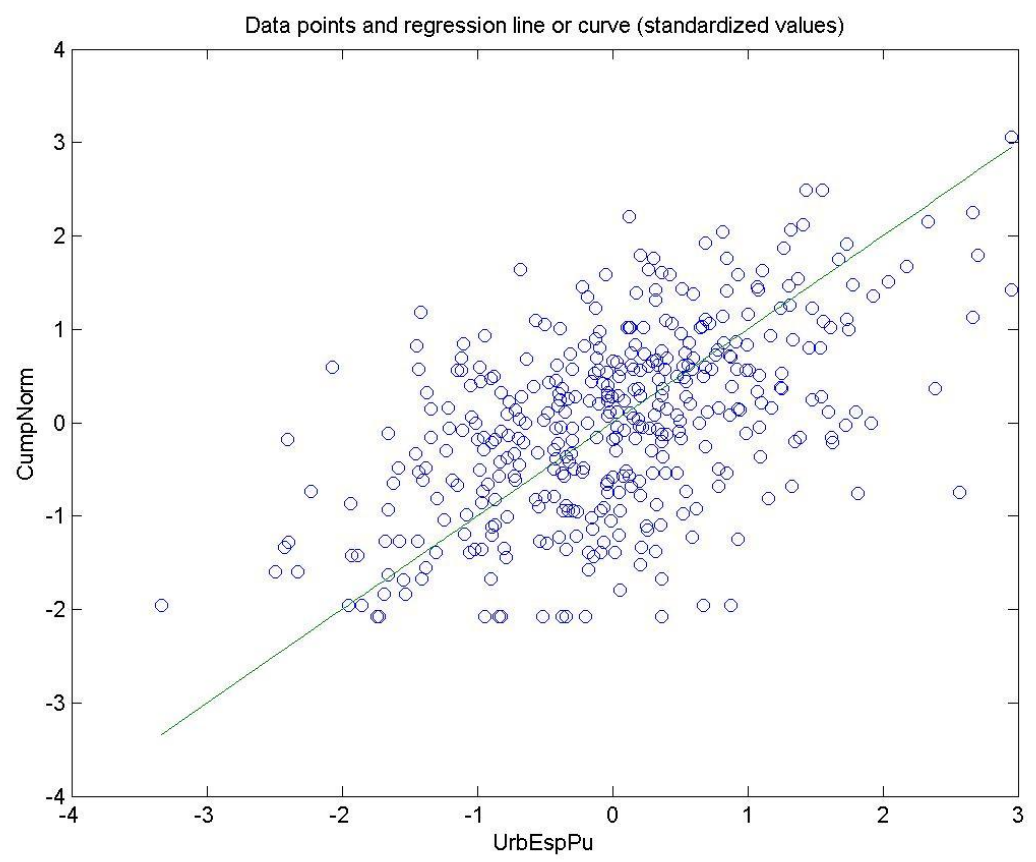




\section{1) Macrothink}

Figure 3: "Perception of Urban Development and Maintenance of Public Space" and the variable "Perception of control and compliance of norms"

Citizens expect that the Quality of Social Services, Employment and Health when taken as an indicator of Control and Compliance of Norms (Figure4), tent along with other objectives, social control (Janowitz, 1975), whether health services, promotion and employment generation or the organization of cultural and sporting events . In this social control is particularly important provides the role of small groups of membership of the individual, the emphasis is on increasing the link of the person with social institutions belonging to local governments which is what will prevent the person from carrying out crimes, from:

1. Improve social roots,

2. Strengthen conformity to conventional values,

3. Promote containment, and

4. Improve internal control, with the understanding that the antisocial actions by the inconsistency appears controller of the primary groups that have not, as its members, internalize the rules and roles needed

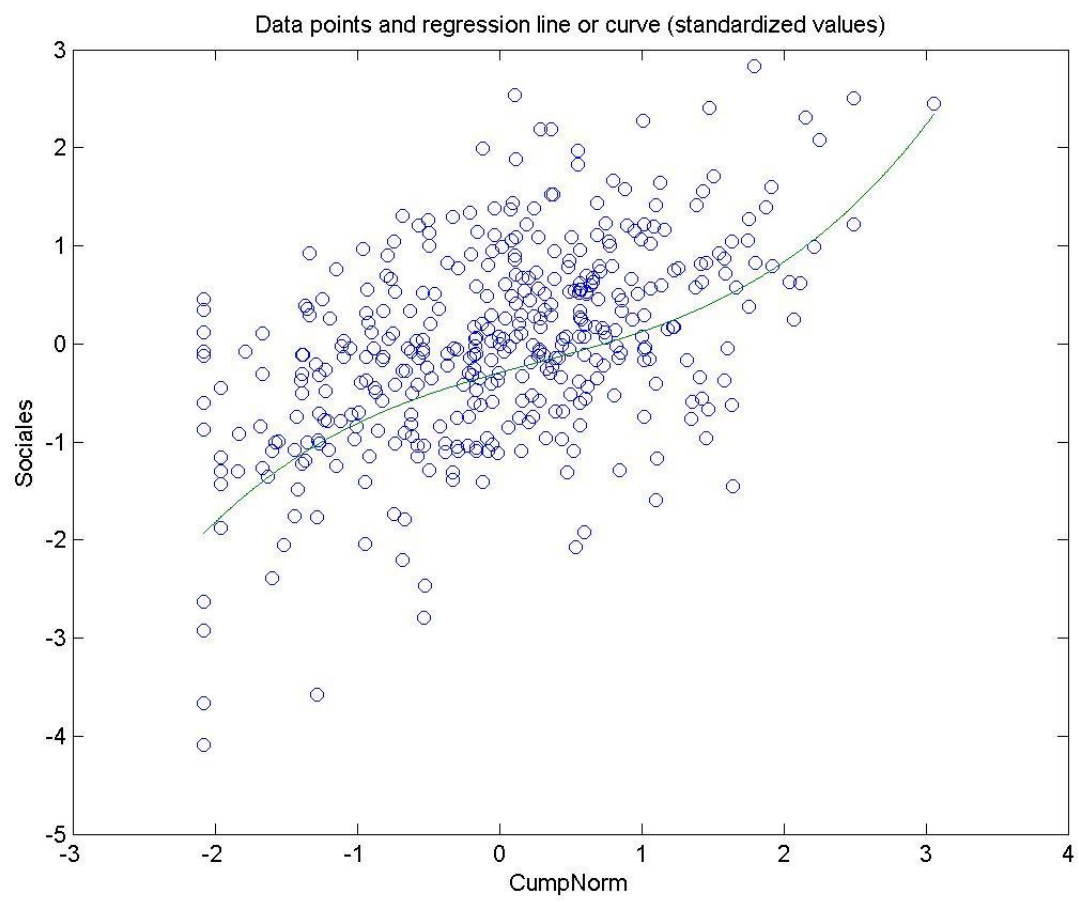


Figure 4: Perceived Quality of Social Services, Employment and Health and the variable Control and Compliance of Norms

The value of municipal taxes does not affect the satisfaction of the citizen, it is likely that the economic influence the expectations and the perceived value of municipal taxes, but only in the event that the economic environment is negative, if otherwise has little effect.

The perception (evaluation of those who have used the services of a particular area and not) is different from satisfaction (evaluation of services only by users in the last month, for example), especially in the variable latent perception of the quality of social services. As a hypothesis we can enunciate that Satisfaction influences the Image of Leadership and this in

\section{Perception.}

Is feasible that the relationship of the citizen satisfaction and leadership image are related to Loyalty mediated by the number of years leadership exercised by the same local power.

\section{Research Implications}

The purpose is identify the aspects of quality of service that residents see as most important regarding to the improvement of their quality of life within the city, discovering intangible variables or factors most influential of citizen's satisfaction about a local government. Is taken as a measuring instrument to obtain the survey data and build a theoretical and empirical model that fits the local government level.

The citizen satisfaction indexes provide information not only about citizen's satisfaction, the rate of fidelity and perceived quality, but also provide suggestions about the factors influencing this satisfaction.

We describe the many and varied possible relationships between the various antecedents and consequences that influence the conceptualization of resident's satisfaction with the management of their local administrators. The quality of service and quality of life can be attributed to different dimensions through which citizens perceive and develop assessments.

The implications for research in the area can be summarized:

1. Adapted models to empirical data taken from different contexts of the cities. 
2. Verify the influence of each area of service quality in citizen's satisfaction about local governments.

3. The impact on the acceptance of local leadership.

4. Identify critical areas and activities to assess management changes.

5. To contribute to sociological theory through empirically corroborated hypotheses, and

6. Identify local societies with different norms and priorities.

\section{References}

1. Aznar, A. (1974), "Infraestructura y regionalización de las provincias españolas: Una aplicación del análisis factorial”, Revista Española de Economía 4, 137- 166.

2. Chenn, Cheng-Hao, Development of a Model to Measure Customer Satisfaction with International Tourist Hotels in Taiwan, A Dissertation In Hospitality Administration, 2009.

3. Efron, B., Rogosa, D., \& Tibshirani, R. (2004). Resampling methods of estimation. In N.J. Smelser, \& P.B. Baltes (Eds.). International Encyclopedia of the Social \& Behavioral Sciences (pp. 13216-13220). New York, NY: Elsevier

4. Eklöf, J. A., 2000. European Customer Satisfaction Index, Pan European telecommunication sector report, Based on the pilot studies 1999.European Organization for Quality and European Foundation for Quality Management, Stockholm, Sweden.

5. Fornell, C., \& Larcker, D.F. (1981).Evaluating structural equation models with unobservable variables and measurement error. Journal of marketing research, 18(1), 39-50.

6. Hair, J. F., R.E. Anderson, and R.L. Tatham. 1987. Multivariate data analysis. Ed. 2. MacMillan, New York. 449 p.

7. Hair, J., Black, B., Babin, B., Anderson, R. E., \& Tatham, R.L. (2006), "Multivariate data-analysis (6th ed.)". Englewood Cliffs: Prentice-Hall.

8. Janowitz, Morris (Chicago University), Social Theory and Social Control, American Journal of Sociology. Vol. 81, 1. Chicago University, 1975. 
9. Johnson Michael D., Anders Gustafsson, Tor Wallin Andreassen, Line Lervik, Jaesung Cha, The Evolution and Future of National Customer Satisfaction Index Model by University of Michigan Business School, Ann Arbor, Michigan 48109-1234, USA University of Karlstad, Service Research Center, 65188 Karlstad, Sweden Nowegian School of Management BI, P.O. Box 580, N-1301 Sandvika, Norway December 2000.

10. Kline, R.B. (1998). Principles and practice of structural equation modeling. New York, NY: The Guilford Press.

11. Lazarsfeld, P. (1985), De los Conceptos a los Índices Empíricos, en Lazarsfeld, P. y Boudon, R. (eds.): Metodología de las ciencias sociales, Vol. 1, Laia. Barcelona, 35-62.

12. Nunnally, J.C., \& Bernstein, I.H. (1994). Psychometric theory. New York, NY: McGraw-Hill.

13. Nunnaly, J.C. (1978). Psychometric theory. New York, NY: McGraw Hill.

14. Wilson, James Q. y George L. Kelling, "Broken Windows. The police and neighborhood safety", The Atlantic Monthly, Vol. 249, № 3, pp. 29-38, 1982.

15. Zeithaml, V. A., Berry, L. L., y Parasuraman, A. (1996). "The Behavioral Consequences of Service Quality". Journal of Marketing, vol. 60, n 2, pp. 31-46. 